22. Шестопалов Г. Г. Петро Опанасович Воронцов / Г. Г. Шестопалов. Дніпропетровськ: Промінь, 1975. - 56 с.

23. Яценко В. Я. Діяльність I. М. Труби в Катеринославській міській думі восени 1917 р. / В. Я. Яценко // Проблеми політичної історії України: зб. наук. пр. - Дніпро: Ліра, 2017. - № 12. - С. 102-117.

24. Яценко В. Я. Питання освіти в діяльності гласних-українців Катеринославської міської думи восени 1917 р. / В. Я. Яценко // Проблеми політичної історії України: зб. наук. пр. - Дніпропетровськ: Вид-во ДНУ, 2013. - № 8. - С. 145-151.

Надійшла до редколегії 16.04.2018

\title{
«Третій шлях» Одеського комітету РСДРП(м) (1918-1920 рр.)
}

Савченко В. А.

Одеський державний університет внутрішніх справ

Проаналізовано діяльність Одеського комітету РСДРП (меншовиків) у революційні роки. Увага концентрується на фракційній боротьбі між лідерами одеського комітету та їх спробах проводити політику «третього шляху», борючись із партійною диктатурою більшовиків та диктатурою білогвардійського режиму.

ключові слова: РСДРП(м); «праві» меншовики; диктатура; профспілки; Міська Дума; Ради

Проанализирована деятельность Одесского комитета РСДРП(м) в революционные годы. Внимание концентрируется на фракционной борьбе между лидерами комитета и их попытках проводить политику «третьего пути», борясь с партийной диктатурой большевиков и диктатурой белогвардейского режима.

Ключевые слова: РСДРП(м); «правые» меньшевики; диктатура; профсоюзы; Городская Дума; Советы

The article is devoted to the analysis of the activities of the Odessa committee of the RSDLP $(\mathrm{m})$ in the revolutionary years. In the years 1918-1920. Many famous menshevik leaders, members of the Central committee of the party, major ideologies and publicists returned to Odessa from Petrograd. The Odessa committee of the $\operatorname{RSDLP}(\mathrm{m})$ had a reputation for being the most «right», anti-bolshevik of all the RSDLP committees $(\mathrm{m})$. The leaders of the RSDLP $(\mathrm{m})$ headed the trade union movement in Odessa, had considerable influence in the local council and in the City Duma, and published newspapers. Party ideologists such as P. Gravi, B. Bogdanov, V. Korobkov, P. Tuchapsky formed the tactics and strategy of the «Third way» of the RSDLP(m), criticizing the «red» and «white» dictatorships. However, political throwing, compromising with the administra-tion of the army of Denikin and the interventionists, ignoring the national question, led the menshe-viks to a crisis inside the structure, to the loss of support from potential avengers. Faction struggle within the Odessa committee of the RSDLP(m). the absence of a clear political line in the pursuit of the policy of the "Third way» in the revolution weakened the movement

(C) В. А. Савченко, 2018 
and influence among the workers. Soviet power, established in February 1920 in Odessa, carried out systematic repressions against the RSDLP(m). Despite the fact that the mensheviks strove to protect the interests of the workers in the conditions of a «white» dictatorship and intervention, the bolsheviks were able to impose on the masses the opinion that they had become «cooperating with the reactionary forces». In 1920, members of the RSDLP(m) were expelled from the councils, central trade union bodies of the city, and individual trade unions.

Keywords: RSDLP(m); «right» mensheviks; dictatorship; trade unions; City Duma; Soviets

Історія РСДРП(м) в Україні має відносно велику історіографію, що розглядає загальні проблеми участі меншовиків у профспілковому русі, діяльність РСДРП(м) у цілому. Дослідження сучасних українських істориків О. Реєнта, О. Мовчана, Р. Вєтрова, С. Донченка, С. Кокіна, В. Греченка, В. Ченцова та ін. висвітлюють історию знищення РСДРП(м) в епоху встановлення тоталітарної держави СРСР, спираючись, переважно, на документи, що відбивають події у Києві, Харкові, Катеринославі [4; 8; 17; 18; 19; 37]. Історія одеського комітету РСДРП(м) часів українських визвольних змагань та перебіг репресій проти однієї з найбільших та найвпливовіших організацій РСДРП(м) в Україні досі залишається недостатньо висвітленою.

Після перемоги Лютневої революції (1917р.) РСДРП(м) стала вагомою політичною силою в Одесі, не маючи конкурентів щодо впливу на робітничий клас. До складу Одеської Ради робітничих депутатів було обрано 194 меншовика, головою виконкому Ради став меншовик I. Гнеденко. Меншовики мали керівні позиції в одеському Центрпрофі та Міський Думі (з кінця 1917 до травня 1918 р. міським головою був висуванець меншовиків В. Богуцький) [13, арк. 3]. Після захоплення влади в Одесі більшовиками (18 січня 1918 р.) меншовики фактично поступилися лідерством, але після вигнання з Одеси більшовиків (13 березня 1918 р.) і до розпуску Одеської ради (15 липня 1918 р.) меншовики та есери домінували в цій структурі. У 1917-1920 pр. одеський комітет РСДРП(м) видавав впливову щоденну газету «Южный рабочий», навколо якої сформувалося керівне ядро: П. Гарві, В. Коробков, О. Сухов, П. Тучабський, I. Астров, Б. Богданов, П. Юшкевич [12, арк. 15-16, 370]. Меншовики керували профспілкою «рабітників друкарскої справи» (голова В. Коробков, заступник Г. Штерн, секретар I. Кейлис), що видавала газету «Одесский печатник» (1917-1918, редколегія: І. Зільберман, I. Кейліс, М. Патлажан). Під орудою РСДРП(м) в Одесі діяла Спілка споживчого товариства «Рабочее дело». 
Одеська організація була не тільки найбільш «правою» 3 усіх організацій РСДРП(м), але й найбагатшою на «зірковий склад». Н. Богданова (донька меншовицького лідера) згадувала: «Незабаром після Жовтневої революції туди (до Одеси - авт.) повернулося досить велике число одеситів - найактивніших діячів Лютого, видатних меншовиків різних напрямків, у тому числі й представників так званої «внутрішньопартійної опозиції» [2, с. 78]. Однією з головних постатей комітету був юрист, одесит Петро Абрамович Гарві (Бронштейн), учасник революційного руху з 1899 р., що пройшов заслання, еміграцію, брав участь в організації грудневого (1905 р.) повстання в Москві. У 1907 р. він був обраний до складу загальнопартійного ЦК РСДРП, 1917 р. входив до складу ЦК РСДРП (об’єднаної), Оргкомітету РСДРП(м), президії Всеросійської Ради профспілок. Після жовтневого перевороту він став одним 3 керівників «правої» течії в РСДРП(м) та вийшов із «центриського» ЦК. 3 1918 р. він мешкав в Одесі, редагував газету «Южный рабочий». В Одесі його супроводжувала дружина «активна меншовичка» Софія Гарві (Фіхман) [35, с. 143].

У 1918 р. на зборах одеської організації РСДРП(м) П. Граві проголосив концепцію «третього шляху». Він вважав, що необхідно провести Установчі збори та скликати Державну нараду, проголосивши на них «єдину російську демократичну республіку... в рамках якої пролетаріат Росії з найбільшим успіхом зможе розгорнути свою визвольну боротьбу за соціалізм», закликавши до боротьби не тільки проти «більшовицької анархії», але й «реставраційних прагнень реакційних кіл великої буржуазії та землевласників... одноосібної військової диктатури, під покровом якої гуртуються реакційні кола» та «національного сепаратизму». Вважаючи неприпустимими будь-які компроміси з радянською владою, П. Граві виступав проти політики «капітуляції перед більшовиками» ЦК РСДРП (м). Він підтримав присутність військ Антанти в Одесі, назвавши «божевіллям та авантюризмом» кликати робітничий клас на боротьбу з «союзниками» [40].

Подібної точки зору дотримувався інший одесит - профспілковий лідер, робітник-друкар Віктор Михайлович Коробков, член РСДРП з 1903 р. За царату він піддавася арештам, пройшов заслання та каторгу. У 1917 р. він став кандидатом у члени ЦК РСДРП(м), очолював одеський комітет РСДРП (м) та профспілки Одеси, був членом Одеської ради. У 1918 р. притягувався до суду Ревтрибуналу як редактор «Южного рабочего». В 1920 р. був заарештований... далі були численні арешти, заслання, концтабори, страта [34, с. 307]. 
До «правих» належав і одесит Борис Осипович Богданов, що у 1905 р. був обраний членом Одеського комітету РСДРП, а 1907 р. - Петербурзького комітету РСДРП, ЦК меншовиків. У 1909 р., після арешту та заслання, він повернувся до Одеси, редагував газету «Наше слово», у 1915 р. став секретарем Робітничої групи Військово-Промислового комітету в Петрограді. Під час революції 1917 р. він обирається членом виконкому Петроградської Ради, делегатом Всеросійського з'їзду рад, членом ВЦВК, членом Оргкомітету РСДРП(м), кандидатом в члени ЦК РСДРП(м). У січні 1918 р. стає одним із керівників руху «Збори уповноважених фабрик та заводів», за що був арештований. У вересні 1918 р. Б. Богданов вийшов із РСДРП(м) через незгоду з політикою «лівого» ЦК, переїхав до Одеси, де увійшов до складу одеського комітету РСДРП(м), брав участь у профспілковому русі, став депутатом ради. У 1920 p. він був знов заарештований, а згодом висланий [3, с. 34-36].

Помітною фігурою серед «правих» меншовиків був Олександр Опанасович Сухов - член партії з 1901 р., у якого була репутація неперевершеного оратора. В 1905-1907 pp. він був організатором Сормовского повстання, страйків одеських моряків, членом комітетів РСДРП(м) в Петербурзі, Твері, Таганрозі, Києві, Луганську, був делегований на Лондонський з'їзд РСДРП. У 1917 р. був делегатом І-го Всеросійського з'їзду Рад, обирався до Центрального Комітету Рад. Із серпня 1917 р. О. Сухов мешкає в Одесі, де обирається у ради, до Міської Думи [12, арк. 10, 284, 572].

Шкільний викладач історії Павло Лукич Тучапській вважався в Одесі за головного ідеолога «правих», він розробляв програму, редагував «Южный рабочий». На зламі XIX-XX ст. він був співзасновником РСДРП, ідеологом Української соціал-демократичної Спілки. 31907 р. мешкав в Одесі, входив до складу одеської «Просвіти» та комітету РСДРП(м). До «старої гвардії» «правих» меншовиків належав і одесит, інженер Яков Мойсейович Грінцер, який у 1905 p. увійшов до одеського комітету, згодом став членом ЦК РСДРП. У 1918 р. він обирається членом ПК меншовиків-оборонців. У 1920 1922 рр. піддавався арештам, був висланий за кордон. «Зірковості» комітету додавав одесит Павло Соломонович Юшкевич - видатний філософ, випускник Сорбонни, публіцист, що наприкінці XIX ст. зв'язав свою долю із марксизмом, брав участь у революції 19051907 pp., а після 1917 р. співпрацював в одеських виданнях РСДРП (м). Інший член комітету Григорій Осипович Біншток (Осіпов) був відомим літератором, лідером «правої» опозиції в РСДРП(м), у 
1922 р. був висланий за кордон разом зі своєю дружиною доктором економічних наук, членом РСДРП(м) Юдіф'ю Гринфельд.

Лідером «лівих» меншовиків був одесит Ісаак Сергійович Астров (Повес). Член РСДРП з 1902 р., у 1917 р. - кандидат у члени, а з травня 1918 р. - член ЦК РСДРП (м). У липні 1918 р. заарештований та висланий до Одеси. В обліковій картці СО Одеського ДПУ повідомлялося: «Чудовий оратор. Один із впливових лідерів Одеської організації, знавець професійного руху. Теоретик. Журналіст. У 1918 р. був головою губпрофсовета в Одесі. 36 липня 1921 р. - голова Комітету Одеської організації РСДРП(м). Дотримується точки зору щодо контакту всіх марксистськи мислячих соціалістів, включаючи й комуністів. Серед робітників і партійних кіл користується величезною популярністю» [6, с. 21]. I. Астров та Б. Богданов були «друзями із підліткових років, пов'язані не тільки особистою дружбою, а й дружбою родин» [2, с. 79].

Впливом серед одеських меншовиків також користувалися: профспілко-вий діяч Р. Штульман (член РСДРП з 1903 р., каторжанин), юрист С. Рисс (член РСДРП з 1900 р., член одеського комітету в 1917-1921 рр.), медінспектор М. Патлажан (член РСДРП з 1898 р., у 1917 р. секретар одеської «Спілки друкарів», член Всеукраїнського Бюро РСДРП), профспілковий працівник та економіст Є. Шатан (висланий з Одеси 1921 р.), депутат Міської Думи О. Станчинський, член правління клубу ім. К. Маркса К. Грінблат, секретар комітету Г. Кон, бухгалтер А. Дудиль, І. Кейліс (висланий з Одеси в Середню Азію), член виконкому Ради в 1917-1918 pр. А. Боркун [12, арк. 17-76].

В грудні 1918 р., після відновлення діяльності одеської Міської Думи, блок меншовиків-есерів «Спілки» мав у Думі 67 голосів 3 120. Цей блок заявив про підтримку Всеукраїнських та Всеросійських Установчих зборів, виборював загальне виборче право [38]. Виконком Ради профспілок тоді очолив «лівий» меншовик І. Астров [39]. Втім РСДРП(м) не змогла використати свій значний потенціал із причин постійних розколів у партії, яка перетворилася в штучне об'єднання конкуруючих фракцій. Розкол між «правими» та «лівими» посилився наприкінці 1918 р., після 3’їзду делегатів земств та міст у Сімферополі, на якому частина меншовицьких «правих» лідерів у союзі з есерами, народними соціалістами, кадетами, СЕРП намагалася створити структури влади для підготовки до скликання Установчих зборів. На думку організаторів з'їзду, новому демократичному урядові повинні були підкоритися збройні сили генерала Денікіна. У березні 1919 р. в Одесі проходили переговори Ради земств та міст, Національного центру, Союзу відродження Росії 148 
(входили меншовики), Спілки відродження Росії, Ради державного об'єднання з питання про утворення демократичного уряду - Директорії [9, с. 79]. На початку 1919 р. під час виборів до складу комітету РСДРП(м) в Одесі були висунуті два «кандидатських» списки «правих» та «лівих». У результаті виборів до комітету увійшло 8 осіб зі списку «правих» (В. Коробков, О. Сухов, П. Тучапський, П. Гарві та ін.) та 6 осіб зі списку «лівих» (І. Астров, А. Боркун, Г. Кон, Клямін, Кунак, Мезенцев) [5]. Разом із тим комітет виступив із резолюцією «Проти терору», засуджуючи революційний терор проти війск Антанти [41].

В наступний період існування радянської влади в Одесі меншовики конкурували с більшовиками за вплив на незалежні від влади профспілки. Адже в Одеському «Центрпрофі» більшовики мали 22 місця, а їхні конкуренти - блок меншовиків, єврейських соціалістів, есерів - 19. Боротьба точилася й в Одеській раді (не переобиралася з 1917 р.), де з 729 членів організації нараховувалося комуністів - 208 (28\%), єврейських соціалістів - 11, правих есерів - 35, меншовиків - 79 [15, с. 10-14]. Конфлікт владних структур із меншовиками призвів до того, що з ради було виключено 114 меншовиків та есерів, під арештом опинився колишній лідер РСДРП(м) I. Гнеденко [28]. Меншовики взялии участь в організації протестів проти диктатури більшовиків на заводі «РТПіТ», страйку залізничників [16, с. 7-8]. «Права» частина РСДРП (м) закликала до «боротьби з антидержавним рухом більшовиків», водночас «ліві» на нараді РСДРП(м) 1 січня 1919 р. у резолюції «Про єдність партії» засудили дії «фракції меншовиків» на земсько-міському з’їзді [36, с. 149]. Головний комітет РСДРП(м) в Україні та Всеукраїнська партійна конференція меншовиків проголосили мобілізацію членів РСДРП(м) до Червоної Армії, крім того «ліві» наполягли на виключенні 3 РСДРП(м) «правих» меншовиків [33, с. 203-204]. Головний комітет вважав, що співробітництво з режимом Денікіна несумісне з приналежністю до партії, відповідно й організацію одеських «правих» розглядав як таку, що полишила партію [31, с. 64-67].

Коли ж у серпні 1919 р. білогвардійці перехопили владу в Одесі, меншовицький комітет очолили «праві» (В. Коробков, П. Гарві, Б. Богданов, Я. Грінцер, О. Сухов, В. Трахтенберг) [12, арк. 15]. У вересні на заседанні Бюро Ради професійних спілок до іiї президії увійшов увесь актив меншовиків (голова В. Коробков), що згодом очолив Президію Виконкому профспілок (голова В. Коробков, заступник В. Трахтенберг секретар I. Лупінський, скарбник 
Пономарьов). Меншовики заявили, що більшовики за часи свого панування «зруйнували» ЦК профспілок [29]. Зрештою, користуючись правами легальної партії, одеські меншовики взяли під свій контроль більшість профспілок, відновили закриту за більшовиків газету «Южный рабочий» [24]. Намагаючись захистити робітників, вони пропонували владі прийняти закон про працю, виборювали визнання підприємцями профспілок та колективних угод, вимагали підвищення платні робітникам та допомоги безробітним, поновлення соціяльного страхування, виплати компенсації звільненим робітникам. Їм вдалося домогтися відновлення «мирових камер», на що міською управою було асигновано 500 тис. крб. Виступаючи проти репресій «білої» влади, лідери меншовиків активно протестували проти реквізиції профспілкових приміщень, проти арештів членів профспілок та катувань у тюрмах [22, с. 35-39].

У той же час РСДРП(м) поступово втрачала свої позиції серед робітників з причини постійних фракційних чвар: «ліві» (група Астрова) шукали компромісів із більшовиками та критикували «правих» (група Гарві) за «співпрацю з Денікіним». «Праві» (більшість в одеському комітеті) закликали до боротьби проти більшовиків, але критично ставилися до «військової диктатури» Денікіна. У серпні 1919 р. $з$ франкції РСДРП(м) вийшов В. Богуцький, а частина «правих», яка пішла на співпрацю з білогвардійською владою, створила нову групу «Единство» (доктор Д. Меєрсон, Я. Ліберман, гласний думи П. Васильєв, член управи та думської фракції К. Хартуларі, колишній голова ради А. Дудюк) [23]. У січні 1920 р. розкол серед одеських меншовиків ще посилився під час переобрання керівництва профспілок та організації загальноміського страйку [32, с. 51].

Розчаруванням політикою меншовиків можна пояснити результати виборів до Міської Думи (листопад 1919 р.), коли на виборах переміг реакційний «Християнський блок», отримавши 86 мандатів, у той час як соціалісти - 8 мандатів («Республіканський блок» 3 меншовиків (В. Коробкова, П. Тучабський, О. Сухов, П. Гарві, Я. Грінцер та ін.) та ПСР). Меншовики закликали одеських робітників до участі у виборах, до боротьби за відновлення Установчих зборів. Але вибори показали, що настрої в Одесі змінилися. Значна частина робітників не взяла участь у виборах із причини загальної апатії та закликів більшовиків бойкотувати останні [26]. На засіданнях нової Міської Думи меншовики виступили у ролі опозиції, бойкотувавши вибори реакційного міського голови В. Колобова [27]. 
Відразу ж опісля повернення радянської влади в Одесу в лютому 1920 p. 68 членів РСДРП було заарештовано. Чекістські джерела вказували, що меншовиків в Одесі тоді налічувалося «понад 2000 осіб» [1, с. 239]. У березні 1920 р. київські меншовики постали перед судом революційного трибуналу, як «відверто реставраторські сили... реакційної демократії» [30]. Більшовицькі пропагандисти звинувачували меншовиків у тому, що ніби вони, входячи до місцевої влади, «відкрито підтримували Добровольчу армію» та проголошували Денікіна «носієм прогресивного демократичного устрою» $[31$, c. 83]. Одеським меншовикам ставили у провину також те, що їх представники брали участь у делегаціях до білогвардійської влади, що вони підтримали рішення 3'їзду профспілок Півдня Росії, на якому провели резолюцію про направлення делегації від профспілок до «Особливої наради з робітничого питання при Денікіні» [4, с. 230231]. Але вся провина меншовиків полягала в тому, що білогвардійці дозволили їм захищати та представляти робітничий клас Одеси. Зрештою, Одеський комітет, звинувачений «у підтримці денікінців та антирадянській спрямованості», був поставлений «поза партією». Член Всеукраїнського комітету РСДРП(м) М. Попов був направлений ЦК РСДРП(м) з надзвичайними повноваженнями в Одесу для розпуску організації, але, не впоравшись із цим завданням, залишив лави меншовиків. Тож розпуск не було проведено в результаті слабкого впливу ЦК РСДРП(м) в одеському комітеті.

Вибори до Одеської ради (березень 1920 р.) стали значним випробуванням для місцевих меншовиків. Незважаючи на тотальні фальсифікації та кричущу нерівність, на виборах меншовики отримали 25 мандатів (із 790) (Б. Богданов, П. Гарві, І. Астров, Вайштейн, Вольфензон, Ганц, Гольдберг, Губерман, Гутман, Кайнер, Келіс, І. Кейліс, Маш, Нейман, Орлов, Полуянов, Рабинов, А. Серпер, Файвілевіч, Фінкель, С. Шатан, Школяр, Г. Штерн, Штульман, Янши) [11, арк. 8-72]. Згодом більшовики провели через Одеську Раду рішення щодо виключення з неї всіх меншовиків та есерів.

У чекістському звіті про одеську РСДРП(м), яка «налічувала в своїх лавах понад 300 організованих, дисциплінованих членів партії», міститься інформація про те, що одеські меншовики: «... оволоділи апаратом деяких профспілок, а особливо друкарів, де склали компактну масу і мали майже половину членів правління. У профспілці шкірняків вони так само мали великий вплив і секретар союзу був меншовиком... Клуб Карла Маркса, в якому досить регулярно відбувалися загальні збори організації, влаштовувалися 
усні газети та проводилася чітка організаційна робота серед членів партії. У цьому клубі були зосереджені всі нитки впливу їх на робітничі маси, тут вироблялися всі плани чергових кампаній з виборів на безпартійні конференції, в ОПО і до Ради робітничих депутатів. В останню їм вдалося провести 25 осіб, 12 місць їм дали голоси друкарів... На першому засіданні ради, так само як і на безпартійній конференції, виступили зі своєю декларацією... користуючись впливом у друкарів, транспортників, шкіряників та радробітників... На пленумі Губпрофради вони так само свого часу користувалися значним впливом» [14, с. 39-40].

Навесні 1920 р. одеські меншовики видали кілька листівок iз приводу виборчої компанії проти безсудних арештів з боку ЧК. 15 серпня лідер «лівих» меншовиків І. Астров був арештований за виступ на засіданні Ради профспілок проти насильницької мобілізації членів профспілки до Червоної Армії. У серпні було арештовано 30 одеських меншовиків (В. Коробков та ін.), що були засуджені до ув'язнення на час громадянської війни. Зрештою, в жовтні 1920 р. чекісти дещо передчасно звітували про ліквідацію одеської організаціі РСДРП(м) [10, арк. 12].

16 грудня 1920 р. у клубі РСДРП(м) відбулися арешти всього активу одеської організації РСДРП(м) (83 особи): «В меншовицькому клубі було проведено арешт членів організації, яких там було захоплено понад 40 осіб. Тієї ж ночі на квартирах було заарештовано понад 30....» [6, с. 22]. П. Гарві згадував: «...здійснено повний розгром місцевої організації та заарештована вся меншовицька фракція Ради робітничих депутатів, у тому числі низка видатних діячів всеросійського та місцевого профспілкового руху: П. Гарві, Б. Богданов, Р. Штульман, І. Лупінський та ін. Арешт цілої фракції Ради та низки профспілкових діячів викликав серед їхніх виборців на фабриках і заводах настільки сильне обурення, що влада була вимушена на один день звільнити заарештованих членів Ради, щоб на ii спеціально скликаному засіданні «оформити» виключення й арешт всієї меншовицької фракції. На засіданні Ради більшовицькою владою було дано урочисту обіцянку, що заарештовані будуть притягнуті до суду [7, с. 119]. Зрештою, «заворушення» серед робітників примусили владу звільнити частину заарештованих, але 19 «найбільш активних ватажків» було вислано з Одеси або запроторено до політізолятору. Арешти на певний час паралізували одеський комітет меншовиків, який перейшов у підпілля.

Прагнучи звести нанівець вплив меншовиків на робітничий 
клас, більшовицька влада поставила собі за мету загалом знищити незалежні профспілки. Чекісти, репресуючи членів одеського комітету РСДРП(м), таким чином «розчистили» для комуністів поле діяльності на заводах та фабриках. Тож диктатура зуміла загнати робітничий клас до контрольованих владою профспілок. Незважаючи на великий інтелектуальний потенціал, досвід профспілкової та політичної боротьби, значну підтримку одеських робітників, меншовики програли на виборах до Міської Думи (1919р.) та до Одеської ради (1920р.). У свою чергу більшовики вміло використали ідейне розшарування у лавах меншовиків, амбіції їх лідерів, відсутність коштів у комітеті. Позбавлення можливостей мати легальні друковані органи, перешкоджання у проведенні лекцій та відкритих зборів, погроми партійних клубів, звільнення з роботи за партійну приналежність, безсудні арешти в підсумку знекровили одеський комітет РСДРП(м), загнавши «умовно легальну» марксистську партію у підпілля в «марксистському раю».

\section{БІБЛІОГРАФІЧНІ ПОСИЛАННЯ}

1. Бажан О. Одеська область у дзеркалі радянських спецслужб / О. Бажан // Лукомор'є. - 2007. - № 1. - С. 233-244.

2. Богданова Н. Б. Мой отец - меньшевик / Н. Б. Богданова. - СПб.: НИЦ «Мемориал», 1994. - 253 с.

3. Богданова Н. Б. Богданов Борис Осипович / Н. Б. Богданова, Г. И. Илящук, В. И. Миллер // Политические деятели России 1917 г. Биографический словарь. - М.: Большая Российская энциклопедия, 1993. - 432 с.

4. Вєтров Р. I. Політичні партії України в перший чверті XX ст. (1900-1925 рр.) / Р. І. Вєтров, С. П. Донченко. - Дніпропетровськ-Дніпродзержинськ, «Поліграфіст», 2001. - 245с.

5. Всегда Вперед! - Москва. - 1919. - 22 февр.

6. Гарви П. А. Дни красного террора в Одессе / П. А. Гарви // Социалистический вестник. - Нью-Йорк - Париж. - 1960. - № 1. - С. 20-31.

7. Гарви П. А. Профсоюзы и кооперация после революции (1917-1920) / П. А. Гарви / Ред.-сост. Ю. Г. Фельштинский. - New-York, Chalidze Publication, 1989. - $210 \mathrm{c}$.

8. Греченко В. А. Україна у добу «раннього» тоталітаризму (20-ті роки ХХ ст.) / В. А. Греченко, О. Н. Ярмиш. - Харків: Вид-во НУВС, 2001. - 276 с. 9. Громов С. Е. Съезд земств и городов юга России (декабрь 1918 г.): Малоизвестные страницы истории Гражданской войны в Крыму / С. Е. Громов // Культура народов Причерноморья. - Симферополь, 1997. - № 2. - С. 260-263. 10. Державний архів Одеської області (далі-ДАОО). - ФП. -3. - Оп.1.-Спр. 893. 11. ДАОО. - Ф.П. - 599. - Оп. 1. - Спр. 567.

12. ДАОО. - Ф.П. - 8065. - Оп. 2. - Спр. 4887.

13. ДАОО. - Ф.Р. - 3829. - Оп. 1. - Спр. 11.

14. Итоги и практика годичной деятельности Одесского губчека. - Одесса: Од. Губчека. 1921. - 144 с. 
15. Коган С. Другий період радвлади на Одещині (квітен-серпень 1919 р.)

/ С. Коган, Н. Межберг // Літопис революції. - 1932. - № 1. - С. 5-40.

16. Коган С. Другий період радвлади на Одещині (квітень-серпень 1919 р.) /

С. Коган, Н. Межберг // Літопис революції. - 1932. - № 2. - С. 1-27.

17. Кокін С. А. Ліквідація більшовиками правоесерівської і меншовицької опозицій в Україні в 1920-1924 pp. / С. А. Кокін, О. М. Мовчан. - Київ: Ін-т історії України АН України, 1993. - 58 с.

18. Мовчан О. М. Придушення меншовицької опозиції в профспілковому русі України (1920-1924 рр.) / О. М. Мовчан // Укр. істор. журн. - 1993. № 3. - C. 37-47.

19. Мовчан О. М. Міжпартійна боротьба у профспілковому русі України (19171922) / О. М. Мовчан, О. П. Реєнт // Укр. істор. журн. - 1995. - № 5. - С. 8-27.

20. На защите революции: Из истории Всеукр. чрезвычайн. комиссии. 1917-1922 рр. Сб. документов и материалов. - Киев: Политиздат Украины, 1971. $-392 \mathrm{c}$.

21. Одесский листок. - Одесса. - 1919. - 25 августа/7 сентября.

22. Одесский листок. - Одесса. -1919. - 7/20 сентября.

23. Одесский листок. - Одесса. - 1919. - 30 сентября/13 октября.

24. Одесский листок. - Одесса. - 1919. - 8/21 октября.

25. Одесский листок. - Одесс. - 1919. - 12/25 ноября.

26. Одесский листок. - Одесса. - 1919. - 10/ 23 грудня.

27. Одесский листок. - Одесса. - 1920. - 12/3 января.

28. Одесские новости. - Одесса. - 1919. - 17/30 августа.

29. Одесские новости. - Одесса. - 1919. - 25 августа/7 сентября.

30. Партия меньшевиков и деникинщина: процесс киевских меньшевиков (21-23 марта 1920 года). - М.: Красная Новь: Главполитпросвет, 1923. - 120 с. 31. Погорілий I. Робітничий рух в Одесі за денікінщини (23 серпня 1919 р. 8 лютого 1920 р.) / І. Погорілий // Літопис революції. - 1931. - № 3. - С. 61-84. 32. Погорілий I. Робітничий рух в Одесі за денікінщини (23 серпня 1919 р. 8 лютого 1920 р.) / І. Погорілий // Літопис революції. - 1931. - № 4. - С. 35-55. 33. Познанська К. В. Меншовицька інтелігенція в добу денікінщини / К. В. Познанська // Інтелігенція і влада. - 2004. - № 3. - С. 199-205.

34. Политическая каторга и ссылка: биографический справочник членов О-ва политкаторжан и ссыльно-поселенцев / Под ред. М. М. Константинова. - М.: Изд-во Всесоюз. О-ва политкаторжан и ссыльно-поселенцев, 1934. - 686 с.

35. Розенталь И. Гарви (Бронштейн) Петр Абрамович / И. Розенталь // Политические партии России. Конец XIX - первая треть XX века. Энциклопедия. - М.: РОССПЭН, 1996. -872 с.

36. Тищенко Е. В. Партия меньшевиков в первые годы Советсткой власти (ноябрь 1917-1921 гг.): дисс. ... кандидата ист. наук: 07.00.01 / Е. В. Тищенко. - М., 1993. -198 с.

37. Ченцов В. В. Політичні репресії в Радянській Україні в 20-ті роки / В. В. Ченцов. - Тернопіль: Збруч, 2000. - 482 с.

38. Южный рабочий. - Одесса. - 1918. - 16(3) декабря.

39. Южный рабочий. - Одесса. - 1918. - 30(17) декабря.

40. Южный рабочий. - Одесса. - 1919. - 9(27) января.

41. Южный рабочий. - Одесса. - 1919. - 24(11) февраля.

Надійшла до редкол.: 09. 04. 2018 